\title{
New Frontiers in Therapy of Peripheral Nerve Sheath Tumors in Patients With Neurofibromatosis Type 1: Latest Evidence and Clinical Implications
}

\author{
AGATA MARJANSKA ${ }^{1}$, PRZEMYSLAW GALAZKA $^{2}$, MARIUSZ WYSOCKI $^{1}$ and JAN STYCZYNSKI ${ }^{1}$ \\ ${ }^{1}$ Department of Pediatric Hematology and Oncology, Nicolaus Copernicus University Torun, \\ Jurasz University Hospital, Collegium Medicum, Bydgoszcz, Poland; \\ ${ }^{2}$ Department of General and Oncological Pediatric Surgery, Nicolaus Copernicus University Torun, \\ Jurasz University Hospital, Collegium Medicum, Bydgoszcz, Poland
}

\begin{abstract}
Almost all individuals with neurofibromatosis type 1 (NF1) develop peripheral nerve sheath tumors (PNSTs), mainly benign neurofibromas, however about 10\% of PNSTs will undergo transformation to malignant peripheral nerve sheath tumors (MPNSTs). Surgical treatment of PNSTs has traditionally been regarded as a standard approach. The availability of new agents that target specific molecular pathways involved in the pathogenesis of PNST has led to a number of clinical trials, which resulted in increased chances for better survival and quality of life. This review presents the latest evidence and clinical implications for new therapies of PNSTs in patients with NF1 emphasizing the potential benefit from the use of Ras/MAPK pathway inhibitors, immunotherapy, chemotherapy or radiation therapy. We present evaluation of current knowledge on available treatment modalities.
\end{abstract}

Neurofibromatosis type 1 (NF1) is an autosomal dominant neurocutaneous disease affecting about 1 in 3500 people worldwide (1). The hallmark clinical features of NF1 include multiple café-au-lait macules, neurofibromas, intertriginous freckling, osseous lesions, Lisch nodules and optic pathway

This article is freely accessible online.

Correspondence to: Agata Marjanska, MD, Department of Pediatric Hematology and Oncology, Collegium Medicum, Nicolaus Copernicus University, Antoni Jurasz University Hospital No. 1, ul. Sklodowskiej-Curie 9, 85-094 Bydgoszcz, Poland. Tel: +48 525854860, Fax: +48 525854087, e-mail: agata.marjanska@wp.pl

Key Words: Peripheral nerve sheath tumor, plexiform neurofibroma, MPNST, neurofibromatosis type 1, NF1, MEK inhibitors, review. gliomas. The disorder is typified by the presence of multisystem tumors, which carries a high risk of malignant transformation $(2,3)$. Nearly $100 \%$ of individuals with NF1 develop benign peripheral nerve sheath tumors (BPNSTs) and in approximately $30-50 \%$ of them atypical and plexiform neurofibromas (PNFs) are found. In about $10 \%$ of NF1 patients, neurofibromas may undergo transformation to malignant peripheral nerve sheath tumors (MPNSTs), which are highly aggressive. The differentiation between atypical neurofibroma and low grade MPNST is probably the most challenging issue in the pathology of peripheral nerve sheath tumors (PNSTs), particularly in NF1 patients. Clinically, atypical tumors often develop as extensive, slowly growing neoplasms, and pain can be a characteristic feature $(4,5)$.

The poor response to currently available therapies underlines the need for more effective, targeted treatment methods for NF1-associated PNSTs $(6,7)$. In this review, we analyzed the latest evidence and clinical implications of new therapies of PNSTs in patients with NF1 emphasizing the importance of patient risk stratification to identify those who are likely to benefit from the use of Ras/MAPK pathway inhibitors, immunotherapy, chemotherapy or radiotherapy. We also analyzed the limitations of administering these therapies to all individuals with NF1-associated PNSTs together with future perspectives.

\section{Methodology}

PubMed searches were performed to identify potentially clinically relevant English-language studies published in the last 15 years. The searches were based on a combination of indexed terms and free text terms ("peripheral nerve sheath tumors", "plexiform neurofibromas", "MPNST", "neurofibromatosis type 1", "NF1") AND ("treatment", "therapy", "resection", "surgical 
treatment", "MEK inhibitors", "kinase inhibitors", "mTOR inhibitors", "immunotherapy", "anti-PD1", "chemotherapy", "radiotherapy"). We analyzed all potentially relevant full papers, and paid particular attention to patient population and applied treatment. We analyzed all publications where the variety of therapies for aggressive PNSTs in pediatric and adult NF1 patients were presented. All types of treatment, including surgery, chemotherapy, immunotherapy, radiation therapy, were considered. We also analyzed reports related to atypical treatment methods, such as diet and vaccine treatment. Our database was supplemented with abstracts from Joint Global Neurofibromatosis Conferences held in 2016 (Italy, Padova) and 2018 (France, Paris) and with information from https://clinicaltrials.gov website. We focused mainly on the results of randomized clinical trials. However, most reports were based only on a relatively small number of patients. This review includes a summary of all NF1-related PNSTs treatment methods found in available medical literature. We described and compared results obtained by the researchers and formulated conclusions, considering which method was highly effective. Each relevant paper was analyzed by two independent investigators. Overlapping data were excluded. In total, 68 papers (including conference abstracts) and 21 clinical trials were found, and qualified as possibly relevant. Finally, 29 reports and 17 clinical trials were selected as relevant to the objective of the study. On the basis of these analyses, we complemented the review with a clinical evaluation that we graded as: positive, negative, optional.

\section{Nomenclature for NF1-associated PNSTs}

PNSTs encompass a wide spectrum of benign and malignant clinicopathologic entities, whose subsets are difficult to classify. The major categories of these tumors are classified as: neurofibroma, schwannoma, perineurioma, hybrid nerve sheath tumors, and MPNSTs $(8,9)$. However, this classification is not appropriate for NF1, as nearly $100 \%$ of individuals with NF1 will develop PNSTs mainly in the form of neurofibromas and their atypical ambiguous subtypes. Since PNSTs required a separate description for NF1 patients, recommendations for diagnosis and classification were proposed at the meeting held at the National Institute of Health (NIH) in 2016 in Bethesda. Characteristics of NF1-associated PNSTs are shown in Table I (7).

The Ki67 index may also be useful in assessing PNSTs in NF1 individuals highlighting proliferative hot spots. While cutaneous, diffuse and atypical neurofibromas usually have low labeling indices $(<2-5 \%)$, high proliferation rates $(>10 \%)$ can aid in the detection of MPNST arising in a neurofibroma (7). Loss of the CDKN2A locus at 9p21, which encodes the cell cycle regulator p16, characterizes early steps in the malignant transformation of neurofibromas. Complete loss of nuclear p16 is a frequent finding in MPNSTs and may be detected in ordinary and atypical neurofibromas indicating that it can be an early modification in malignant progression, but by itself is not adequate to diagnose malignancy $(7,10)$.

\section{Imaging Evaluation of PNSTs - Differentiation of Benign and Malignant Lesions}

Magnetic resonance imaging (MRI) is the most useful method for evaluating the anatomical extent of the lesion before surgical planning $(5,11)$. However, the morphological imaging features demonstrated limited diagnostic precision for differentiation of benign and malignant PNSTs with specificities of $18-82 \%$ and sensitivities of $18-94 \%$. In MRI, MPNSTs present specific morphological properties including irregular shapes and margins, heterogeneity within tumor and peritumoral oedema (12-14).

Ultrasound or computed tomography (CT) may be useful in some patients for image-guided biopsies and bone scintigraphy can be helpful in assessing osseous involvement $(11,15)$.

FDG-PET/CT-guided percutaneous biopsy is an effective procedure and the most dependable approach for untimely detection of NF1-associated MPNST $(16,17)$. Benign PNFs demonstrate low fludeoxyglucose (FDG) uptake, whereas MPNSTs depict moderate to high FDG accumulation. Commonly standard uptake values (SUV), the amount of FDG uptake, usually range between 1.0-3.99 in benign tumors and between 3.1-21.4 in malignant lesions. There is an overlap between BPNSTs and MPNSTs for SUV values between 2.5 to 3.5 . Therefore, it seems that the symptomatic PNFs with SUV $\geq 3.5$ should be excised and lesions with SUV 2.5-3.5 should have precise clinical evaluation. FDG$\mathrm{PET} / \mathrm{CT}$ can be useful in the diagnosis of MPNST with specificity ranging from $72 \%$ to $95 \%$ and sensitivity ranging from $91 \%$ to $100 \%(15,18,19)$. The optimum time for measuring SUV in patients with symptomatic PNFs is 240 min after injection of FDG (19).

Whole-body hybrid PET/MRI is a viable alternative for evaluation of the potential occurrence of MPNSTs in NF1 patients, with sensitivity similar to that of PET/CT. Furthermore, X-ray dose reduction with PET/MR approaches $50 \%$ compared to PET/CT, a vital concern in this patient population with tumor suppressor gene impairment $(15,20,21)$.

Diffusion-weighted MRI (DW-MRI) without administration of intravenous contrast material improves precision compared to morphological MRI in the differentiation of malignant and benign lesions in NF1-patients. DW-MRI can be a very valuable complementary method, when borderline glucose metabolism of tumors is observed in PET imaging (12). 
Table I. Nomenclature for NF1-associated PNSTs (4, 5, 7, 8, 32, 92-94).

\begin{tabular}{|c|c|c|}
\hline Diagnosis & Characteristics & Comments \\
\hline Neurofibroma & $\begin{array}{l}\text { - Benign neoplasm from nonmyelinating Schwann cells } \\
\text { - Wavy nuclei, wispy cell processes and a myxoid to } \\
\text { collagenous matrix ("shredded carrots") } \\
\text { - IHC: SOX10 (+), S100 (+), lattice-like CD34+ } \\
\text { fibroblastic network }\end{array}$ & $\begin{array}{l}\text { The most common are localized cutaneous neurofibromas } \\
\text { which usually occur as a single lesion. They can result in } \\
\text { a fusiform expansion of the large nerve trunk. Diffuse } \\
\text { neurofibromas are characterized by a plaque-like } \\
\text { enlargement commonly in the region of head and neck. } \\
\text { Cutaneous or diffuse neurofibromas seldom evolve } \\
\text { into MPNST. }\end{array}$ \\
\hline Plexiform neurofibroma & $\begin{array}{l}\text { - Involvement of plural adjacent nerve fascicles and/or } \\
\text { multiple components of the nerve plexus } \\
\text { - delineated by EMA+ perineurial cells }\end{array}$ & $\begin{array}{l}\text { Can implicate skin layers, fascia, bones, muscles and } \\
\text { penetrate the viscera. The adjacent skin may demonstrate } \\
\text { hyperpigmentation or hypertrichosis. The hypertrophy } \\
\text { of surrounding connective tissues and underlying bones } \\
\text { is often observed. The most popular locations are the } \\
\text { head, neck, trunk and extremities. PNF has a potential } \\
\text { for malignant degeneration. }\end{array}$ \\
\hline Neurofibroma with atypia & - Scattered bizarre nuclei & $\begin{array}{l}\text { Atypical neurofibroma has been suggested to be } \\
\text { premalignant lesions based on their CDKN2A loss, as } \\
\text { is recognized in MPNST, and can transform to MPNST. }\end{array}$ \\
\hline Cellular neurofibroma & $\begin{array}{l}\text { - Neurofibroma with hypercellularity } \\
\text { - Mitotic index: }<1 / 50 \mathrm{HPF}\end{array}$ & $\begin{array}{l}\text { There are no definitive data on risk for } \\
\text { progression to MPNST. }\end{array}$ \\
\hline $\begin{array}{l}\text { Atypical neurofibromatous } \\
\text { neoplasm of unknown } \\
\text { biologic potential } \\
\text { (ANNUBP) }\end{array}$ & $\begin{array}{l}\text { - neoplasm from Schwann cell with } \geq 2 / 4 \text { : } \\
\text { 1) cytologic atypia, } \\
\text { 2) loss of neurofibroma architecture, } \\
\text { 3) hypercellularity, }\end{array}$ & $\begin{array}{l}\text { Possibly ANNUBPs are not malignant in most } \\
\text { NF1 patients. }\end{array}$ \\
\hline $\begin{array}{l}\text { Low-grade MPNST } \\
\text { (frequency: } 15 \% \text { ) }\end{array}$ & $\begin{array}{l}\text { 4) mitotic index: }>1 / 50 \mathrm{HPF} \text { and }<3 / 10 \mathrm{HPF} \\
\text { - Characteristics like ANNUBP } \\
\text { - Mitotic index: 3-9/10 HPF and no necrosis }\end{array}$ & $\begin{array}{l}\text { The appearance of new, growing, or permanent pain in } \\
\text { the area of neurofibroma is an important signal that } \\
\text { should always be carefully evaluated. MPNST may occur } \\
\text { at any age with the same frequency in both sexes. }\end{array}$ \\
\hline $\begin{array}{l}\text { High-grade MPNST } \\
\text { (frequency: } 85 \% \text { ) }\end{array}$ & $\begin{array}{l}\text { - Mitotic index: }>10 / 10 \mathrm{HPF} \\
\text { - Mitotic index: } 3-9 / 10 \mathrm{HPF} \text { and presence of necrosis }\end{array}$ & $\begin{array}{l}\text { The median age for MPNST in NF1-patients is } 20-40 \\
\text { years. Primary tumors usually occur in the extremities } \\
(45-59 \%) \text {, within the trunk }(17-34 \%) \text {, or head and neck } \\
(19-24 \%) \text {. In most cases, the dimension of the tumor is } \\
>5 \mathrm{~cm} \text { before starting treatment, and up to } 50 \% \text { of } \\
\text { patients present with metastases, commonly to the lung. } \\
\text { Usually aggressive, with 5-year survival rates at } 34 \%-60 \% \text {. }\end{array}$ \\
\hline
\end{tabular}

MPNST: Malignant peripheral nerve sheath tumor; IHC: immunohistochemistry; HPF: high power fields; PNF: plexiform neurofibroma.

\section{Pathogenesis of PNSTs in NF1}

The NF1 syndrome is the consequence of mutations in NF1 tumor suppressor gene on chromosome 17q11. More than 500 mutations have been identified, with the majority resulting in a loss of function of the neurofibromin protein, which is encoded by the $N F 1$ gene $(22,23)$. Neurofibromin is highly expressed in numerous organs, but is mostly abundant in the brain tissue, spinal cord, and peripheral nervous system. A variation in a single germline allele is sufficient to cause the NF1 syndrome, but according to Knudson's "2-hit hypothesis", tumor formation appears to require the loss of function of a second allele $(22,24)$. Neurofibromin also participates in the regulation of histogenesis, and cellular maintenance or repair. Accordingly, NF1 is a disorder of not only tumor predisposition, but also of dysplasia (25).
Neurofibromin is a protein that accelerates the intrinsic hydrolysis of Ras from its GTP- to inactive GDP-bound conformation (26). In healthy cells, Ras is in the inactive conformation and is responsible for correct proliferation, transformation, differentiation, and apoptosis. Upon NF1 inactivation, Ras hyperactivity and the consequent activation of various downstream proliferative and survival pathways, like the mammalian target of rapamycin (mTOR), mitogen-activated protein kinase (MAPK), or AKT (Mouse breed AK thymoma, termed protein kinase B, or PKB) pathways are observed $(5,22)$. Hence, by accelerating the conversion of Ras-GTP to Ras-GDP, neurofibromin negatively regulates Ras-dependent signaling cascades. In the pathophysiology of NF1, when neurofibromin is defective, Ras-GTP is constantly activated, which results in unrestrained stimulation of various pro-growth pathways (26). 
Biallelic loss of neurofibromin is responsible for the development of PNSTs in patients with NF1 syndrome. However, the pathway to tumorigenesis is distinctly more complicated; NF 1 mutations are probably not sufficient to induce neoplastic change. Murine experiments have also shown the significance of haploinsufficient NF1-mast cells for accelerating PNF growth. In addition to Ras activation, maturation, recruitment and proliferation of mast cells have been demonstrated to be mediated by the stem cell factor (SCF), the ligand for the KIT receptor tyrosine kinase (RTK), suggesting SCF/KIT-dependent tumorigenic tumorstromal interactions in PNFs. The next molecular pathway leading from benign lesion to MPNST in NF1 syndrome remains uncertain. Figure 1 depicts the multiple major nodes engaged in the pathogenesis of MPNSTs, involving angiogenesis, intracellular signaling pathways, and interactions with the environment of the tumor $(5,27)$.

\section{Indications for Treatment of PNSTs}

Cutaneous neurofibromas should be removed when they cause transient itching and stinging, cosmetic problems or catch on clothing. Resection of benign PNFs is usually difficult because of encroachment of the lesion on adjacent structures and its inseparable vascular nature. Surgical intervention carries a high risk of life-threatening hemorrhage, especially in cases of facial PNFs (28).

About $50 \%$ of PNFs occur in the region of the face, head, neck, and larynx. Serious controversy persists regarding the indications and timing of surgical interventions for PNFs of the head and neck. In pediatric PNFs the management is based on serial imaging studies to establish impending risk to the airway and other critical neck structures. There are definite indications for surgical resection of large tumors of the head and/or neck: 1) to exclude malignant transformation in a fast enlarging mass; 2) to increase airway patency; 3) to alleviate symptoms caused by compression of neural structures, particularly in paraspinal PNFs; 4) to achieve aesthetic results, particularly in individuals with trigeminal lesions, bearing in mind the related risk of facial nerve palsy (29).

PNFs involving the orbit, eyelid, periorbital, and facial structures are called "orbital-periorbital PNFs" (OPPNFs). The best management for newly diagnosed OPPNFs is close observation with regular ophthalmological and MRI evaluations because a lot of OPPNFs will be not symptomatic and progressing. Indications for treatment can be 1) young age of the patient; 2) rapid growth of PNFs; 3) presence of a concurrent optic pathway glioma; 4) symptomatic tumor (i.e., strabismus, vision loss, glaucoma, proptosis, ptosis, amblyopia); 5) infiltration of OPPNF into other structures (i.e., cavernous sinus) (30).

Based on a review of published studies, the following indications for surgical interventions for PNSTs of plexiform/diffuse type of limbs should be considered: 1) exploration/biopsy: rapidly enlarging mass and/or an unusual or novel mass with long-lasting pain are the predominant findings leading to the decision to explore the affected region; 2) nodular PNF: this tumor type has a higher risk of malignant degeneration if situated in deeper body regions; 3 ) superficial PNF: in the cases of not extensive involvement of the body region, when surgery and rehabilitation can be implemented; 4) invasive PNF: the surgical objectives are often limited to improvements in the outline of the body without affecting the tumor load of deeper body regions. An important distinction in this patient group is the restriction of tumor growth to the soft tissue or simultaneous tumorassociated alteration of soft tissue and bones; 5) palliative treatment: amputation of the affected limb with progressive PNF or MPNST, to increase survival chances $(31,32)$.

Clearly, the future of favorable control of PNFs lies in the development of effective nonsurgical modalities. MPNST tumors always require early and aggressive treatment (28). In each case of PNST, management decisions should include input from a multidisciplinary group (30).

\section{Treatment of PNSTs}

Management of PNSTs has traditionally been surgical, because these tumors are not radiosensitive and, given their slow growth rates, only limited benefit has been seen with chemotherapy (29). The accessibility of agents that target Ras signaling and other pathways involved in the pathogenesis of PNFs has led to a number of clinical trials. The development of genetically engineered mouse models of NF1-related tumors has led to preclinical trials of targeted drugs (33). The outcome of treatment of PNSTs in individuals with NF1, based on review of reported cases, is presented in subsequent sections.

Surgical treatment and other invasive methods. Surgery with complete removal of the lesion with tumor free margins is the most effective approach to treat patients with PNSTs. However, due to the large extent of many lesions, complete resection of these tumors is hardly feasible and may cause severe iatrogenic damage. Furthermore, PNFs may present in the form of diffuse enlargement of the affected body region $(11,29,32)$. Current surgical experience has shown that recurrence rates for BPNSTs range from $1.3 \%$ to $54 \%$ and are higher in pediatric PNFs $(29,30,32,34-37)$. Outcome is largely influenced by tumor histopathology, type of mutation and tumor location $(34,38-40)$. Due to unsatisfactory results from surgical treatments, more effective and safer operating methods are sought. Callefi et al. have proposed a technique named compartmentalization, which is based on neurofibroma's mechanical ischemia before surgical excision, without preoperative embolization or use of sclerosing agents. 


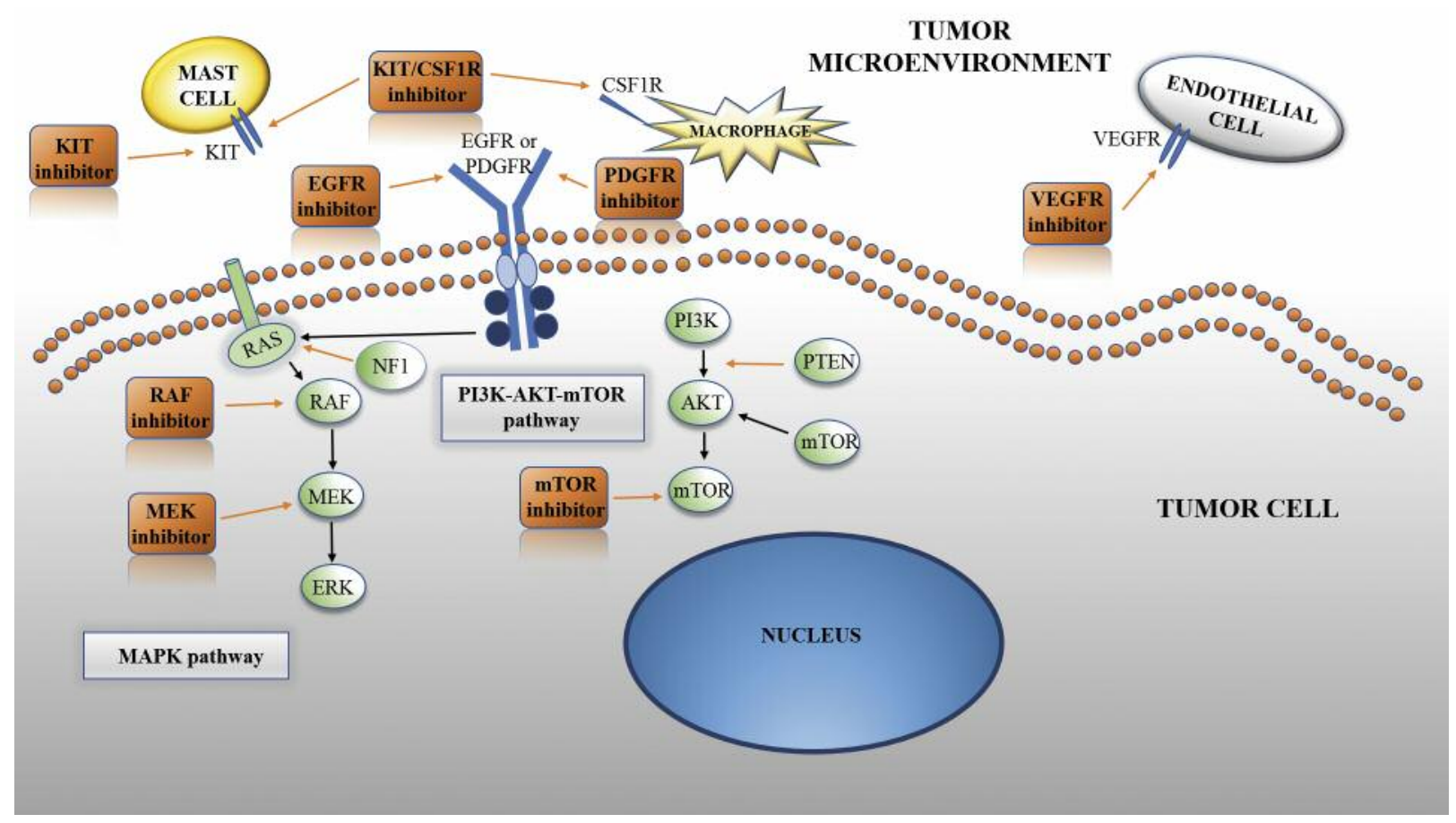

Figure 1. Major molecular mechanisms implicated in the pathogenesis of MPNSTs, which include various KIT signaling cascades, epigenetic regulation and tumor microenvironment interactions. The mechanisms of action of potential small-molecule inhibitors targeting each of the mentioned machineries are denoted (27). KIT: Receptor tyrosine kinase; CSF1R: colony stimulating factor 1 receptor; EGFR: epidermal growth factor receptor; PDGFR: platelet-derived growth factor receptor; VEGFR: vascular endothelial growth factor receptor; RAF: rapidly accelerated fibrosarcoma; MEK: mitogen-activated protein kinase; ERK: extracellular-signal-regulated kinase; MAPK: mitogen-activated protein kinase; PI3K: phosphatidyl inositol 3-kinase; AKT: mouse strain AK thymoma; mTOR: mammalian target of rapamycin.

This technique allows complete surgical excision of big size PNFs, otherwise inoperable, in a single surgical approach, significantly decreasing the risk of bleeding and also allows histopathological examination of PNFs (41).

In addition to expected management with routine imaging and surgical resection, possible alternative treatment options for non-cutaneous PNSTs include cryoablation, radiosurgery, microwave ablation and radiofrequency ablation. There are only single reports of percutaneous treatment of PNSTs (4247). The treatment objective for BPNSTs within main peripheral nerves should be lesion control and not complete ablation, since most normal fibers travel within the capsule of the tumor. The management of MPNST is much more aggressive than that of BPNST, so a tissue diagnosis should be received prior to percutaneous treatment (42). Additionally, there is no proven benefit of carbon dioxide laser treatment over surgical removal of neurofibromas, but laser can be useful for some small lesions. Nevertheless, the risk of recurrence or a hypertrophic scarring after resection still exists (28). It is a crucial factor to balance the present activity of the patient with the risk of future loss of a function induced by an invasive intervention (30).
MEK inhibitors. Mitogen-activated protein kinase (MEK) is a key protein in the mitogen activated protein (MAP) kinase signal transduction pathway for many growth factor receptors that supply growth signals to tumor cells (48).

Selumetinib is an inhibitor of MEK $1 / 2$, which can mediate anti-tumor effects in PNFs by inhibiting Ras signaling (33). The phase I trial of selumetinib in 24 pediatric NF1-patients (3-17 y) with inoperable PNFs showed unprecedented activity with objective responses (PNF volume decrease $\geq 20 \%$ ) in $71 \%$ of enrolled children. None of the patients had disease progression. However, a slow tumor regrowth was observed in several individuals who required dose reductions due to toxicity. This fact suggests that a minimal selumetinib tissue concentration may be required for anti-tumor activity. In 2019, U.S. FDA approved selumetinib for the treatment of pediatric patients ( $\geq 3 \mathrm{y}$ ) with NF1 symptomatic and/or progressive, inoperable PNFs $(33,48)$.

Only a few case reports of patients with NF1-dependent PNFs effectively treated with trametinib have been reported so far $(49,50)$. All currently ongoing clinical trials with MEK inhibitors for NF1-patients with PNFs or MPNST are listed in Table II (51). 
Table II. Review of current clinical trials with MEK inhibitors for patients with NF1-related PNFs/MPNST (51).

\begin{tabular}{ccccc}
\hline Trial & Phase & Eligibility & Regimen tested and schedule & Objective \\
ClinicalTrials.gov \\
identifier
\end{tabular}

MEK 1/2 Inhibitor Selumetinib (AZD6244 Hydrogen Sulfate) in Adults With Neurofibromatosis Type 1 (NF1) and Inoperable Plexiform Neurofibromas An Intermediate Access Protocol for Selumetinib for Treatment of Neurofibromatosis Type 1 Intermittent Dosing of Selumetinib In Childhood NF1 Associated Tumors (INSPECT) AZD6244 Hydrogen Sulfate for Children With Nervous System Tumors

Phase II Study of Binimetinib in Children and Adults With NF1 Plexiform Neurofibromas (NF108-BINI)

Trametinib for Pediatric Neuro-oncology Patients With Refractory Tumor and

Activation of the

MAPK/ERK Pathway.

MEK Inhibitor PD-0325901

Trial in Adolescents and

Adults With NF1

(MEK Inhibitor)

Study to Investigate Safety,

Pharmacokinetic (PK),

Pharmacodynamic (PD) and

Clinical Activity of Trametinib

in Subjects With Cancer or

Plexiform Neurofibromas and

Trametinib in Combination

With Dabrafenib in Subjects

With Cancers Harboring

V600 Mutations

Pediatric Long-Term

Follow-up and

Rollover Study

\section{SARC031: MEK}

Inhibitor Selumetinib

(AZD6244) in Combination

With the mTOR Inhibitor

Sirolimus for Patients With

Malignant Peripheral

Nerve Sheath Tumors
$2 \geq 18$ y; NF1; inoperable PNF that causes morbidity or is growing

2 2-18 y; NF1; inoperable progressive/ symptomatic PNF

1/2 3-18 y; NF1; inoperable $\mathrm{PNF}$ and/or progressive OPG

1/2 12-18 y; NF1; inoperable PNF

2

$\geq 18$ y (Arm A) or 1-17 y (Arm B); NF1; progressive or causing significant morbidity PNF

1/2 $1 \mathrm{~m}-25 \mathrm{y}$; PNF or LGG; NF1 positive or negative

2

$$
\begin{aligned}
& \geq 16 \text { y; NF1; growing } \\
& \text { or symptomatic, } \\
& \text { inoperable PNF }
\end{aligned}
$$

$1 / 2$

$1 \mathrm{~m}-17 \mathrm{y} ; \mathrm{NF} 1$ associated PNFs or other solid tumors with BRAF V600 mutation

$4 \geq 1 \mathrm{y}$; patients who received monotherapy or combination with dabrafenib and trametinib $2 \geq 12 \mathrm{y}$; unresectable or metastatic, sporadic or NF1 associated MPNST
Selumetinib - $50 \mathrm{mg}$, orally, every 12 hours every day continuously ( 1 cycle=28 days)

Selumetinib (no information available about dose)

Selumetinib - orally twice daily on 5 out of 7 days (without more data)

Selumetinib - orally, every

12 hours on continuous daily schedule for cycles of 28 days until unacceptable toxicity

Binimetinib - orally, every

12 hours, $45 \mathrm{mg} /$ dose in

adults ( 1 cycle -28 days) (no information

available about dose in pediatric patients)

Trametinib: $0.025 \mathrm{mg} / \mathrm{kg} /$ day, up to a total of

18 cycles $(1$ cycle $=28$ days $)$

PD-0325901 - orally, $2 \mathrm{mg} / \mathrm{m}^{2} /$ dose ( $\max 4 \mathrm{mg}$ ), schedule: 3 week on/1 week off

Trametinib - orally, once daily, dose: 0.0125-0.040 mg/kg/day; $\max 3 \mathrm{mg}$ Dabrafenib - $3 \mathrm{mg} / \mathrm{kg}$ with dose escalation of $0.75 \mathrm{mg} / \mathrm{kg} /$ day

\section{Trametinib} Dabrafenib (no information available about doses) Selumetinib - orally, $50 \mathrm{mg}$ twice daily continuously Sirolimus - orally, $4 \mathrm{mg}$ once daily with a cycle 1 day 1 loading dose of $12 \mathrm{mg}$ ( 1 cycle=28 days)

\author{
RR: $\geq 20 \%$ decrease NCT02407405 \\ of PNFs volume
}

No data

NCT03259633

Phase 1: MTD

NCT03326388

Phase 2: ORR

Phase 1: MTD

NCT01362803

Phase 2: PRR, CRR

Change from baseline

NCT03231306 target tumor

volume at 12 months

Phase 1: ORR

NCT03363217

Phase 2: TTP, PFS,

OS, safety and tolerability of drug

Tumor volume response, NCT02096471 toxicity, ORR, QoL

Safety and tolerability

NCT02124772 of the drugs; tumor volume response on trametinib and dabrafenib used as monotherapy and in combination

Evaluation of AEs and NCT03975829 clinical benefits

Evaluation of clinical NCT03433183 benefits, toxicities,

PFS, OS

NF1: Neurofibromatosis type 1; PNF: plexiform neurofibroma; ORR: objective response rate; OPG: optic pathway glioma; MTD: maximum tolerated dose; PRR: partial response rate; CRR: complete response rate; LGG: low grade glioma; TTP: time to progression; PFS: progression-free survival; OS: overall survival; QoL: quality of life; AEs: adverse events; MPNST: malignant peripheral nerve sheath tumor. 
Tyrosine kinase inhibitors. Imatinib is a specific inhibitor of a number of tyrosine kinase (TK) enzymes. There are many TK enzymes in the body and imatinib is specific for the TK domain in ABL, stem cell factor (c-KIT) and plateletderived growth factor receptor (PDGF-R). The BCR-ABL pathway includes many downstream pathways such as the Ras/MAPK pathway, which stimulates proliferation in a growth factor-independent manner. In an imatinib phase II trial, PNF volume decreased from baseline by at least $20 \%$ in only 6 of 36 patients $(17 \%)(52,53)$. A phase III study that evaluated the efficacy and safety of imatinib mesylate treatment in adult patients with NF1-related MPNST was terminated early due to slow recruitment and lack of effect (NCT00427583) (51).

Nilotinib is an active TK inhibitor which targets ABL (and the oncogenic BCR-ABL), together with several other RTKs including those for c-KIT, collagen and PDGF-R. It has a number of advantages over imatinib, including a favorable toxicity profile. Wei et al. have demonstrated an inhibitory effect of nilotinib on viability and proliferation of PNFderived Schwann cells and PNST-cells in vitro with $50 \%$ inhibitory concentration values lower than those of imatinib. In this in vivo model, the more potent effect of nilotinib over imatinib was also revealed. These results showing that nilotinib shows a more potent antitumor effect than imatinib in vivo and in vitro, suggest the possible clinical application of nilotinib for PNFs (54). In the early phase I clinical trial with nilotinib, 3 out of 6 adult patients with NF1-associated PNFs completed the study. In 2 patients, stabilization of the disease was observed and 1 individual had tumor progression (NCT01275586) (51).

Sunitinib malate is a multi-targeted RTK inhibitor that seems to be an exceptional candidate for the treatment of NF1-associated PNFs. Ferguson et al. have shown that sunitinib inhibits gain-in-functions within base cellular constituents of the PNF microenvironment including NF1mast cells and fibroblasts, driven by hyperactive, Rasdependent signaling. Further, they demonstrated that sunitinib malate induces growth arrest or regression of PNFs in genetic modified mice validating inhibition of various TKRs as a possible treatment for NF1-individuals with PNFs (55). Safety profile and effectiveness of sunitinib were evaluated in 19 NF1-patients (3-65 y) with PNFs through a phase I clinical trial. The study was terminated, because one patient died due to an uncertain cause, but possibly related to the drug (NCT01402817) (51).

Sorafenib is a potential inhibitor for RTK. Pre-clinical testing of sorafenib in a genetically susceptible mouse model for NF1-related PNF showed significant decreases in lesion size. Kim et al. have conducted a phase I trial of sorafenib in 9 children (3-18 y) with NF1 and inoperable PNFs, where no tumor shrinkage and poor tolerance of the drug was observed (56).
Cediranib is a potent inhibitor of vascular endothelial growth factor (VEGF) RTK. The phase II trial NCT00326872 included patients with NF1 and PNF and/or neurofibroma near the spine. The trial was terminated due to slow accrual prior to interim analysis (51).

Cabozatinib is a multitargeted TK inhibitor. In a phase II study (NCT02101736), cabozatinib was used in 23 subjects ( $\geq 16 \mathrm{y}$; median age $23 \mathrm{y}$ ) with NF1 and clinically significant PNFs. The objective response rate to drug was defined as $\geq 20 \%$ reduction in tumor volume at the end of 12 cycles. Among 19 eligible patients, $8(42 \%)$ had an objective response. None of the patients had PNF progression during treatment $(51,57)$.

Interferons. Interferon- $\alpha$ is a cytokine predominantly produced by leukocytes in response to infections and has immunoregulatory, antiviral, antiproliferative and antitumor activities. The mechanisms include the activation of immunomodulatory factors (cytotoxic T-lymphocytes, NK cells, monocytes), the induction of increased cell surface expression of class I MHC antigens, and inhibition of secretion of anti-angiogenic factors (58).

Pegylated interferon- $\alpha-2 \mathrm{~B}$ (pegIFN- $\alpha-2 \mathrm{~B}$ ) was evaluated in a phase $\mathrm{I}$ trial that included 17 patients (1.9-34.7 $\mathrm{y}$; median age $9.3 \mathrm{y}$ ) with NF1-related PNFs. Five of the patients $(5 / 17 ; 29.4 \%)$ showed a $15 \%-22 \%$ decrease in tumor volume. Five patients developed tumor progression 11-24 months after the beginning of treatment (59). In a phase II trial with pegIFN- $\alpha-2 \mathrm{~B}$, tumor volume decrease by at least $20 \%$ was identified in only 4 of $82(4.9 \%)$ patients (1.6-21.4 $\mathrm{y}$; median age $10 \mathrm{y}$ ) (58).

Kebudi et al. have studied 5 patients (1.1-12 y; median age 8 y) with unresectable, progressive and symptomatic PNFs. All of them had experienced relief from pain during treatment with interferon- $\alpha-2 \mathrm{Aa}(\mathrm{IFN}-\alpha-2 \mathrm{~A})$, and in one case radiologic response was observed (60).

mTOR-inhibitors. Converging evidence has demonstrated that neurofibromin regulates growth of cells by negatively influencing the mammalian target of rapamycin (mTOR) pathway. Mammalian TOR is a central integrator of a number of cellular processes, like cell proliferation, growth and survival, protein translation and angiogenesis. Furthermore, mTOR pathway activation propagates tumor proliferation in NF1 genetically engineered mouse models and human NF1related tumor explants (61). The suppression of mTOR by rapamycin significantly inhibited the growth of NF1-related malignancies in a genetically engineered murine model. The results of these trials suggest that rapamycin (sirolimus) or its derivatives, such as temsirolimus or everolimus, might be used as a potential therapy for NF1-tumors.

In the study of the safety and efficacy of everolimus for life-threatening, surgically intractable, internal PNFs in adult 
NF1-patients the drug had no effect on tumor volume (62). Hua et al. have presented 3 cases of young NF1-patients ( 8 y, $16 \mathrm{y}, 17 \mathrm{y})$ who were treated with sirolimus for lifethreatening PNFs. After 12-months follow-up, no difference from baseline in PNFs volume was demonstrated. However, in all 3 cases pain had decreased, which led to cessation of all analgesics (63). Another trial assessed sirolimus as a therapy for inoperable NF1-related internal PNFs in a pediatric population (3-17.7 y; median age $8.2 \mathrm{y}$ ). The time to progression ( $>20 \%$ increase in the sum of the volumes of all index PNFs) was significantly shorter in the placebo group (11.9 months) than in the sirolimus group (15.4 months) (61).

Drug combinations including mTOR inhibitor are being currently tested in clinical trials for MPNST: ganetespib + sirolimus (NCT02008877), bevacizumab + everolimus (NCT01661283), pexidartinib + sirolimus (NCT02584647), selumetinib + sirolimus (NCT03433183). The results have not been published yet (51).

PD1-inhibitors. Programmed death-ligand 1 (PD-L1) expression on PNFs cell membrane has been found and identified as a predictive marker correlated with the therapeutic response to anti PD-L1/anti-PD-1 checkpoint inhibitor monoclonal antibodies. The location and type of lymphocytic infiltrate have significant influence on response to immune checkpoint inhibitors. Tumors with infiltration of CD8+ cells are considered good candidates for therapy with anti-PD-1 drugs. The tumor infiltrating lymphocytes (TILs) or high expression of PD-L1 on PNF cells suggest that patients can be responsive to treatment with immune checkpoint inhibitors (64).

Currently, there are two phase II clinical trials, where adult patients with unresectable MPNST are treated with the use of humanized monoclonal IgG4 antibody directed against programmed death-1 (PD-1) cell surface receptor: The first study examines the efficacy of pembrolizumab monotherapy (NCT02691026) and the second study the combined therapy with nivolumab (anti-PD-1 agent) and ipilimumab (antiCTLA-4 antigen monoclonal antibody) (NCT02834013). No results are available yet for these clinical trials (51).

Conventional chemotherapy. The standard of care in locally advanced MPNST is to receive local disease control, primarily using operating techniques. The primary goal is to acquire negative surgical margins. If there is an increased risk of unresectability of the tumor, neoadjuvant chemotherapy or/and radiotherapy can be applied, particularly in patients with a tumor size of $>5 \mathrm{~cm}$ and when a quick reduction of tumor mass is necessary. Currently there are no randomized clinical trials available where chemotherapy is evaluated in MPNST. The data are limited to retrospective, single analyses of case series (65). In a few reports and clinical trials, the sensitivity of MPNST to various types of classical chemotherapeutic agents was assessed. The results of these studies are presented in Table III (66-71).

Madhankumar et al. have demonstrated IL13R $\alpha 2$ expression in a few MPNST cell lines. IL13 conjugated liposomal doxorubicin was formulated and demonstrated cytotoxic effect following binding and internalization in a MPNST cell culture model. A sequential in vivo study in the MPNST sciatic nerve tumor model indicated that unconjugated liposomal doxorubicin was less efficient in inhibiting tumor progression compared to IL13 conjugated liposomal doxorubicin. This, additionally supports that IL13 receptor targeted nanoliposomes can be an important approach for treating MPNSTs (72).

Radiation therapy. There are many controversies regarding the role of radiation therapy (RT) in the management of MPNST, because it may be a malignancy-risk factor for patients with NF1. According to some of these studies, RT decreases the risk of local recurrence and improves local control (LC), however, it does not result in better survival. Most specialists recommend RT in high-risk patients: large tumor size $(>5 \mathrm{~cm}$ or $>10 \mathrm{~cm})$, high grade tumors and margin positive tumors. There is also some disagreement about optimal timing of RT: preoperatively versus postoperatively. In a preoperative setting, tumor volume and its relation to adjacent organs is accurately seen in CT scanning and therefore radiation planning is more reliable. However, a large tumor pushes the critical organs and acts as a natural shield. Theoretically, tumor with intact blood supply shows a better response to RT $(73,74)$.

Bishop et al. have reviewed the medical records of 71 patients (16-88 y; median age $39 \mathrm{y}$; $37 \%$ with NF1-status) treated with RT and surgery for locally advanced MPNSTs. Preoperative RT was used in 23 individuals $(32 \%)$ to a median dose of 50 (50-60) Gy, and 48 (68\%) patients received postoperative RT to a median dose of 64 (45-70) Gy. Median follow-up was 118 months. The 5-year LC, disease-specific survival and distant metastasis free survival rates were $84 \%, 66 \%$, and $62 \%$, respectively. Uncertain or positive surgical margin status was the only certain factor negatively associated local relapse at 5 years (28\% vs. $5 \%$ for negative margins). Therapy with the combination of surgery and RT achieved more favorable LC (75).

In a phase II clinical trial, 50 patients $(\geq 16 \mathrm{y})$ with primary or locally recurrent paraspinal sarcomas or chordomas were evaluated. Treatment consisted of preand/or postoperative proton or photon RT with or without radical resection. RT median dose was 76.6 (59.4-77.4) Gy. In follow-up, the 5 and 8-year LC rates were $94 \%$ and $85 \%$ for patients with primary tumors and $81 \%$ and $74 \%$ for the entire group (76).

In a retrospective study, 11 patients (29-79 y, median age 47 y, 27\% with NF1) with MPNSTs, who had been treated 
Table III. Chemotherapy available for MPNSTs (66-71).

\begin{tabular}{|c|c|c|c|c|c|c|}
\hline & References & Chemotherapy & Schedule & Patients & Outcome measures & Comments \\
\hline \multirow[t]{4}{*}{$\begin{array}{l}\text { Neoadjuvant } \\
\text { chemotherapy }\end{array}$} & $(66)$ & $\begin{array}{l}\text { Ifosfamide (I) } \\
\text { Doxorubicin (D) } \\
\text { Etoposide (E) }\end{array}$ & $\begin{array}{c}4 \text { cycles }(21 \mathrm{~d}): \\
2 \times \mathrm{I} / \mathrm{D}, 2 \times \mathrm{xI} / \mathrm{E} \\
\text { I: } 1800 \mathrm{mg} / \mathrm{m}^{2} ; \mathrm{d} 1-5 \\
\text { D: } 37.5 \mathrm{mg} / \mathrm{m}^{2} ; \mathrm{d} 1-2 \\
\text { E: } 100 \mathrm{mg} / \mathrm{m}^{2} ; \mathrm{d} 1-5\end{array}$ & $\begin{array}{l}\text { - NF1-MPNST: } \\
34 \text { (median age: } \\
33 \text { y; 8-66 y) } \\
\text { - sporadic-MPNST: } \\
14 \text { (median age: } \\
40 \text { y; 13-72 y) }\end{array}$ & $\begin{array}{c}\text { PR ( }>50 \% \text { decrease } \\
\text { of target lesions): } \\
17.9 \% \text { (NF1) vs. } \\
44.4 \% \text { (sporadic) }\end{array}$ & $\begin{array}{l}\text { Due to the small } \\
\text { number of patients, } \\
\text { the study did not } \\
\text { have sufficient } \\
\text { statistical power. }\end{array}$ \\
\hline & (71) & $\begin{array}{c}\text { Ifosfamid (I) } \\
\text { Epirubicin (Ep) }\end{array}$ & $\begin{array}{l}\text { 5-11 cycles I/Ep } \\
\text { I: } 1800 \mathrm{mg} / \mathrm{m}^{2} ; \mathrm{d} 1-5 \\
\text { Ep: } 60 \mathrm{mg} / \mathrm{m}^{2} ; \mathrm{d} 1-2\end{array}$ & $\begin{array}{c}\text { P1: NF1, } 27 \text { y } \\
\text { P2: NF1, } 35 \text { y } \\
\text { P3: NF1, } 59 \text { y } \\
\text { P4: non-NF1, } 29 \text { y } \\
\text { P5: non-NF1, } 54 \text { y }\end{array}$ & $\begin{array}{c}\text { Decrease in tumor: } \\
\text { P1: } 39 \% \\
\text { P2: } 0 \% \\
\text { P3: } 47 \% \\
\text { P4: } 15 \% \\
\text { P5: } 33 \%\end{array}$ & No comments. \\
\hline & $(67)$ & $\begin{array}{l}\text { Standard CTH: } \\
\text { Ifosfamid (I) } \\
\text { Epirubicin (Ep) }\end{array}$ & $\begin{array}{l}\text { Group A: } 3 \text { cycles; } \\
\text { I: } 3000 \mathrm{mg} / \mathrm{m}^{2} ; \mathrm{d} 1-3 \\
\text { Ep: } 60 \mathrm{mg} / \mathrm{m}^{2} ; \mathrm{d} 1-2\end{array}$ & $\begin{array}{l}\text { Group A: } 144(\geq 18 \mathrm{y}) \text { : } \\
\text { - MPNST: } 15(10 \%) \\
\text { - other types*:129 (90\%) }\end{array}$ & $\begin{array}{c}\text { 4-years OS and } \\
\text { DFS: } 62 \% \text { (Group A) } \\
\text { vs. } 38 \%(\text { Group B) }\end{array}$ & $\begin{array}{c}\text { Disease criteria: } \\
\text { high-risk (high } \\
\text { malignancy grade, } \\
\text { size } \geq 5 \mathrm{~cm}, \\
\text { deeply located), } \\
\text { localized STS. } \\
\text { Study: randomized, } \\
\text { phase III. }\end{array}$ \\
\hline & & $\begin{array}{l}\text { Histotype-tailored } \\
\text { chemotherapy - } \\
\text { for MPNST: } \\
\text { Ifosfamid (I) } \\
\text { Etoposide (E) }\end{array}$ & $\begin{array}{l}\text { Group B: } 3 \text { cycles; } \\
\text { - for MPNST: } \\
\text { E: } 150 \mathrm{mg} / \mathrm{m}^{2} ; \mathrm{d} 1-3 \\
\text { I: } 3 \mathrm{~g} / \mathrm{m}^{2} ; \mathrm{d} 1-3 ; \\
\text { - histotype-tailored } \\
\text { chemotherapy for } \\
\text { other types* }\end{array}$ & $\begin{array}{c}\text { Group B: } 142(\geq 18 \text { y): } \\
\text { - MPNST: } 12(8 \%) \\
\text { - other types*: } 130(92 \%)\end{array}$ & & \\
\hline \multirow[t]{3}{*}{$\begin{array}{l}\text { Adjuvant } \\
\text { chemotherapy }\end{array}$} & (68) & $\begin{array}{l}\text { Ifosfamide (I) } \\
\text { Epirubicin (Ep) }\end{array}$ & $\begin{array}{c}\text { I: } 3000 \mathrm{mg} / \mathrm{m}^{2} ; \mathrm{d} 1-3 \\
\text { Ep: } 60 \mathrm{mg} / \mathrm{m}^{2} ; \mathrm{d} 1-2 \\
\text { Arm A: } 3 \\
\text { preoperative cycles } \\
\text { Arm B: } 3 \text { preoperative }+ \\
2 \text { postoperative cycles }\end{array}$ & $\begin{array}{l}\text { Arm A: } 164(\geq 18 \text { y) } \\
\text { Arm B: } 164(\geq 18 \text { y) }\end{array}$ & $\begin{array}{c}\text { 10-years OS and RFS: } \\
58 \%(\text { Arm A) vs. } \\
61 \%(\text { Arm B) }\end{array}$ & $\begin{array}{c}\text { Disease criteria: } \\
\text { high-risk (grade } 3 \text {, } \\
\text { deep site, } \\
\text { size } \geq 5 \mathrm{~cm} \text { ), } \\
\text { localized STS. } \\
\text { Study: randomized, } \\
\text { phase III. }\end{array}$ \\
\hline & $(70)$ & $\begin{array}{l}\text { Doxorubicin (D) } \\
\text { monotherapy or } \\
\text { combined with } \\
\text { other CTH }\end{array}$ & D: $50-90 \mathrm{mg} / \mathrm{m}^{2} /$ cycle & 18 RCTs: 1953 ( $\geq 18$ y) & $\begin{array}{l}\text { - OS: } 1124 / 1953(57.5 \%) \\
\text { - LR: } 296 / 1700(17.4 \%) \\
\text { - DR: } 553 / 1700(32.5 \%) \\
\text { - OR: } 884 / 1747(50.6 \%)\end{array}$ & $\begin{array}{l}\text { Meta-analysis: } \\
18 \text { RCTs for } \\
\text { patients with } \\
\text { localized, } \\
\text { resectable STS. }\end{array}$ \\
\hline & (69) & $\begin{array}{c}\text { Four categories } \\
\text { of CTH }\end{array}$ & D: $75 \mathrm{mg} / \mathrm{m}^{2}$ & $\begin{array}{l}\text { MPNST: } 175 \\
(15.6-76.3 \mathrm{y} ; \\
\text { median age } 42.6 \mathrm{y}) \\
\text { Other types STS: } \\
2500(10.0-79.5 \mathrm{y} ; \\
\text { median age } 51.5 \mathrm{y}) \\
\text { MPNST: } 61\end{array}$ & $\begin{array}{l}\text { Follow-up } 4.1 \mathrm{y} \\
\text { (MPNST vs. other } \\
\text { STS histotypes): } \\
\text { - RR: } 21 \% \text { vs. } 22 \% \\
\text { - PFS } 17 \text { vs. } 16 \text { weeks } \\
\text { - OS: } 48 \text { vs. } 51 \text { weeks } \\
\text { PFS: } 17 \text { weeks }\end{array}$ & $\begin{array}{l}\text { Chemotherapy- } \\
\text { naive STS } \\
\text { patients treated } \\
\text { on } 12 \text { pooled } \\
\text { nonrandomized and } \\
\text { randomized trials. }\end{array}$ \\
\hline
\end{tabular}

Doxorubicin (D) Ep: $75-150 \mathrm{mg} / \mathrm{m}^{2}$

or Epirubicin (Ep)

2 Ifosfamide (I)

3 Doxorubicin (D)

Ifosfamide (I)

I: $5-12 \mathrm{~g} / \mathrm{m}^{2}$

D: $50-75 \mathrm{mg} / \mathrm{m}^{2}$

I: $5 \mathrm{~g} / \mathrm{m}^{2}$

No data.
Other types STS: 940

MPNST: 26

Other types STS: 383

MPNST: 58

Other types STS: 789

MPNST: 30

Other types STS: 388
PFS: 9.4 weeks

PFS: 26.9 weeks

PFS: 10.4 weeks

Vincristine $(\mathrm{V})$

Adriamycin (A)

Dacarbazine (Da)

NF1: Neurofibromatosis type 1; MPNST: malignant peripheral nerve sheath tumor; PR: partial response; CTH: chemotherapy; OS: overall survival; DFS: disease-free survival; STS: soft tissue sarcoma; RFS: relapse-free survival; RCT: randomized controlled trial; LR: local recurrence; DR: distant recurrence; OR: overall recurrence; RR: response rate (to CTH); PFS: progression-free survival. *Other types: high-grade myxoid liposarcoma, leiomyosarcoma, synovial sarcoma, undifferentiated pleomorphic sarcoma. 
Table IV. Evaluation of current knowledge on possible clinical treatment modalities in NF1-associated PNSTs.

\begin{tabular}{|c|c|}
\hline Treatment & Current evaluation \\
\hline Surgical treatment and other invasive methods & $\begin{array}{l}\text { Positive: should be regarded as "gold standard" initial approach, } \\
\text { if tumor localization and size are favorable }\end{array}$ \\
\hline Pre-emptive pharmacological approach & Negative: no data available \\
\hline Sequential pharmacological treatment after surgery & Positive: due to high rate of recurrences post surgery \\
\hline Pharmacological treatment & Optional: conflicting data in severely symptomatic disease \\
\hline MEK inhibitors & Positive: low rate of tumor progression \\
\hline Tyrosine kinase inhibitors & Optional/negative: conflicting results, some severe failures \\
\hline Interferons & Negative: negligible response to treatment \\
\hline mTOR inhibitors & $\begin{array}{l}\text { Optional/negative: no reduction in tumors volume was observed after monotherapy; } \\
\text { further studies are required, including combination therapy }\end{array}$ \\
\hline PD1 inhibitors & $\begin{array}{l}\text { Optional: no clinical data are available, although preclinical study and } \\
\text { data from other settings are promising }\end{array}$ \\
\hline Chemotherapy & Positive: increases the chance of complete surgical resection of MPNST \\
\hline Radiation therapy: preemptive & Negative: no clinical data available \\
\hline Radiation therapy: pre-operational & $\begin{array}{l}\text { Optional/positive: controversial due to low radiosensitivity; } \\
\text { however, might improve final outcome }\end{array}$ \\
\hline Radiation therapy: post-operational & $\begin{array}{l}\text { Optional/positive: controversial due to low radiosensitivity; } \\
\text { however accumulating data about positive outcome }\end{array}$ \\
\hline Other therapeutic options & Optional: conflicting data, based on small groups of patients \\
\hline
\end{tabular}

with carbon $\mathrm{C} 12$ ion irradiation with 60 Gy cumulative dose, were analyzed. Median follow-up was 17 months (range=331 months) and during this time three local progressions, one distant failure and two deaths were observed (OS-75\%). Carbon ion irradiation yields very promising short-term LC in patients suffering from unresectable or gross residual MPNSTs (77).

In a retrospective review, the outcomes of 33 patients with MPNSTs (18 NF1-associated, median age $15 \mathrm{y} ; 15$ sporadic tumors, median age $41 \mathrm{y}$ ) were evaluated. Twenty patients were treated with RT in a median dose of $58.5 \mathrm{~Gy}$. The median survival of all participants was 46.5 months and $43.7 \%$ 5-year OS was observed. The extent of resection, histology grade and tumor location were the most important prognostic factors. The analysis showed that RT may be an effective method to achieve local and symptomatic control with well-tolerated toxicities (78).

In a retrospective review of 15 patients (10-38 y, median age 25) with NF1-associated MPNST who underwent treatment with RT (median dose 50 Gy; 44-63), therapeutic strategies with RT resulted in satisfying LC rates and were well-tolerated by the patients. The OS was $100 \%, 79.2 \%$ and $53.2 \%$ at 1,3 and 5 years, respectively. No secondary malignancies associated with radiation treatment were reported (79).

Other therapeutic options. Tipifarnib is a selective inhibitor of farnesyltransferase (a target to block Ras signaling) that has an antiproliferative effect. In a phase II trial of 62 NF1patients (3-21.5 y; median age $9.7 \mathrm{y}$ ) with progressive PNFs, the time to progression (TTP), rather than tumor response, was the primary endpoint of assessment of the activity of tipifarnib. Compared to placebo, tipifarnib did not significantly prolong TTP. The largest decrease in PNF volume was $11 \%$, in only one patient (80).

Pirfenidone is an antifibrotic drug that modulates the expression of growth factors or cytokines that are relevant to fibrosis (81). In a phase II study of 24 adults (15-67 y) with NF1-associated unresectable PNFs, pirfenidone was welltolerated and decreased tumor size by $\geq 15 \%$ in $29.2 \%(7 / 24)$ patients. Improvement in neurologic function and reduction in pain were also observed (82). In another phase II trial of pirfenidone in 36 younger patients (3-18.8 y, median age $8.9 \mathrm{y}$ ) the median TTP was 13.2 months. The drug was well-tolerated, but did not demonstrate satisfactory activity to warrant further evaluation in NF1-children with progressive PNFs (81).

The oncogene MET encodes for a RTK that is involved in the progression and metastasis of most solid human cancers. Several studies implicate oncogenic MET signal activation in NF1-related MPNST disease progression. Peacock et al. have used a mice model to demonstrate that NF1-MET MPNSTs were sensitive to the highly selective MET inhibitor, capmatinib.

The treatment with capmatinib and trametinib led to reduction of response variability and enhanced suppression of tumor growth, and also suppressed both Ras/ERK and PI3K/AKT signaling. These data expand understanding of the role of MET signaling in MPNST progression and suggest a potential therapeutic niche for NF1-patients with MPNSTs (83). 
Poly(ADP) ribose polymerase (PARP) inhibitors are primarily used in malignancies with known defects in DNA repair genes. In in vitro studies, it has been proven that PARP1 and PARP2 are highly expressed in MPNST tissue samples, and PARP inhibitor (Olaparib) might be an effective therapy in MPNST and should be further investigated for its potential clinical use in this type of malignancy (84).

Accumulating evidence indicates that a desmoplastic reaction involving high deposition of the glycosaminoglycan Hyaluronic Acid (HA) in extracellular matrix can lead to poor drug penetrance and efficacy. Human MRI images display large regions of poor uptake of contrasting agent, and a human tissue microarray shows $100 \%$ positivity of HA deposition trough all samples, including PNFs. Breaking down this physical barrier is a promising potential avenue to improve drug penetrance, perfusion, and efficacy. In Kellers' research combination treatment with pegylated hyaluronidase (PEGPH20) and doxorubicin was more effective as compared to monotherapy. Preliminary results also show an increase of OS when PEGPH20 is combined with a targeted MEK inhibitor. PEGPH20 shows promising therapeutic benefit in targeting physical barriers in MPNSTs. Improved drug delivery and efficacy will open avenues to further drug combinations for this currently incurable malignancy (85).

Curcumin is a turmeric-derived polyphenol that has been shown to interact with several molecular targets implicated in carcinogenesis. There are reports that after 6 months, NF1-individuals adopting a Mediterranean diet enriched with curcumin (1200 mg/day) presented a significant reduction in the volume and/or number of cutaneous neurofibromas. In one patient, a large cranial PNF presented a $28 \%$ reduction in volume $(86,87)$. Furthermore, it was shown that curcumin may increase the sensitivity of neurofibromin deficient MPNST cells to TRAIL (TNF-related apoptosis-inducing ligand) while downregulating anti-apoptotic proteins (88).

Viability and proliferation of some MPNST cells can be reduced by all-trans retinoic acids (ATRA), and combination of ATRA and MEK inhibitor demonstrated additive reduction in cell viability (89).

Currently research on gene therapy for the treatment of NF1 related MPNSTs is ongoing. The development of adenoassociated viruses (AAVs)-based treatment using the NF1GAP-related domain to deactivate Ras activity in MPNSTs and in pre-cancerous cells in NF1-patients has been initiated (90).

Therapy with oncolytic Measles Virus encoding thyroidal sodium iodide symporter (MV-NIS) has significant antitumor properties in many types of cancers. Local administration of MV-NIS vaccine into MPNST-derived tumors resulted in significant reduction in tumor size and improved survival in an in vitro study (91). A phase I trial on vaccine therapy is currently evaluated (NCT02700230) (51).

\section{Evaluation of Treatment Modalities}

NF1 is one of the most common genetic disorders that equally affects all races and both sexes. While it is one of the most frequent diseases predisposing to development of malignancy with the preponderance of PNSTs, no effective treatment is available so far. Based on extensive review of the published data, we present an evaluation of the current knowledge on possible clinical treatment modalities (Table IV). This evaluation suggests that future studies should focus on development of pre-emptive strategies and post-surgical approaches, based on molecularly-defined targeted treatment, improved systemic/local chemotherapy or local radiotherapy. In conclusion, no effective PNSTs treatment was found except complete surgical resection, which can be performed in selected patients with NF1. It seems that the purpose of the other methods of therapy is the regression of tumor size in order to increase the chances for surgical treatment. As the clinical outcome is still not satisfactory, further studies are necessary to bring clinical benefit.

\section{Conflicts of Interest}

The Authors declare that they have no conflicts of interest regarding this study.

\section{Authors' Contributions}

AM: study concept and design, data acquisition and analysis, manuscript preparation; PG: data acquisition, data analysis and interpretation; MW: quality control of data, data analysis and interpretation, manuscript review; JS: study design, quality control of data, data analysis and interpretation, manuscript review and editing.

\section{References}

1 Boyd KP, Korf BR and Theos A: Neurofibromatosis type 1. J Am Acad Dermatol 61(1): 1-14; quiz 15-16, 2009. PMID: 19539839. DOI: $10.1016 /$ j.jaad.2008.12.051

2 Karaconji T, Whist E, Jamieson RV, Flaherty MP and Grigg JRB: Neurofibromatosis type 1: Review and update on emerging therapies. Asia Pac J Ophthalmol (Phila), 2018. PMID: 30387339. DOI: $10.22608 /$ APO.2018182

3 Marjanska A, Jatczak-Gaca A, Wojtkiewicz A, Wysocki M and Styczynski J: Demographical profile and spectrum of multiple malignancies in children and adults with neurocutaneous disorders. Anticancer Res 38(9): 5453-5457, 2018. PMID: 30194202. DOI: 10.21873/anticanres.12877

4 Prados MD: Plexiform neurofibromas, trial design, and the definitions of "progression" and "treatment failure". Neuro Oncol 16(5): 617-618, 2014. PMID: 24714524. DOI: 10.1093/neuonc/nou050

5 Farid M, Demicco EG, Garcia R, Ahn L, Merola PR, Cioffi A and Maki RG: Malignant peripheral nerve sheath tumors. Oncologist 19(2): 193-201, 2014. PMID: 24470531. DOI: 10.1634/theoncologist.2013-0328 
6 Varin J, Poulain L, Hivelin M, Nusbaum P, Hubas A, Laurendeau I, Lantieri L, Wolkenstein P, Vidaud M, Pasmant E, Chapuis N and Parfait B: Dual mtorc1/2 inhibition induces antiproliferative effect in NF1-associated plexiform neurofibroma and malignant peripheral nerve sheath tumor cells. Oncotarget 7(24): 35753-35767, 2016. PMID: 26840085. DOI: 10.18632/oncotarget.7099

7 Miettinen MM, Antonescu CR, Fletcher CDM, Kim A, Lazar AJ, Quezado MM, Reilly KM, Stemmer-Rachamimov A, Stewart DR, Viskochil D, Widemann B and Perry A: Histopathologic evaluation of atypical neurofibromatous tumors and their transformation into malignant peripheral nerve sheath tumor in patients with neurofibromatosis 1-a consensus overview. Hum Pathol 67: 1-10, 2017. PMID: 28551330. DOI: 10.1016/j.humpath.2017.05.010

8 Rodriguez FJ, Folpe AL, Giannini C and Perry A: Pathology of peripheral nerve sheath tumors: Diagnostic overview and update on selected diagnostic problems. Acta Neuropathol 123(3): 295319, 2012. PMID: 22327363. DOI: 10.1007/s00401-012-0954-z

9 Chikkannaiah P, Boovalli MM, Nathiyal V and Venkataramappa S: Morphological spectrum of peripheral nerve sheath tumors: An insight into world health organization 2013 classification. J Neurosci Rural Pract 7(3): 346-354, 2016. PMID: 27365950. DOI: $10.4103 / 0976-3147.182768$

10 Rhodes SD, He Y, Smith A, Jiang L, Lu Q, Mund J, Li X, Bessler W, Qian S, Dyer W, Sandusky GE, Horvai AE, Armstrong AE and Clapp DW: Cdkn2a (Arf) loss drives nf1associated atypical neurofibroma and malignant transformation. Hum Mol Genet 28(16): 2752-2762, 2019. PMID: 31091306. DOI: $10.1093 / \mathrm{hmg} / \mathrm{ddz} 095$

11 Hao X, Levine D, Yim J, Qi C, Firestone L, Beiser I, Leone E, Woelffer K and Mirkin G: Schwannoma of foot and ankle: Seven case reports and literature review. Anticancer Res 39(9): 51855194, 2019. PMID: 31519632. DOI: 10.21873/anticanres.13715

12 Well L, Salamon J, Kaul MG, Farschtschi S, Herrmann J, Geier KI, Hagel C, Bockhorn M, Bannas P, Adam G, Mautner VF and Derlin T: Differentiation of peripheral nerve sheath tumors in patients with neurofibromatosis type 1 using diffusion-weighted magnetic resonance imaging. Neuro Oncol 21(4): 508-516, 2019. PMID: 30496452. DOI: 10.1093/neuonc/noy199

13 Matsumine A, Kusuzaki K, Nakamura T, Nakazora S, Niimi R, Matsubara T, Uchida K, Murata T, Kudawara I, Ueda T, Naka $\mathrm{N}$, Araki N, Maeda M and Uchida A: Differentiation between neurofibromas and malignant peripheral nerve sheath tumors in neurofibromatosis 1 evaluated by MRI. J Cancer Res Clin Oncol 135(7): 891-900, 2009. PMID: 19101731. DOI: 10.1007/s00432008-0523-y

14 Demehri S, Belzberg A, Blakeley J and Fayad LM: Conventional and functional MR imaging of peripheral nerve sheath tumors: Initial experience. AJNR Am J Neuroradiol 35(8): 1615-1620, 2014. PMID: 24763412. DOI: 10.3174/ajnr.A3910

15 Assadi M, Velez E, Najafi MH, Matcuk G and Gholamrezanezhad A: PET imaging of peripheral nerve tumors. PET Clin 14(1): 81-89, 2019. PMID: 30420224. DOI: 10.1016/j.cpet.2018.08.013

16 Azizi AA, Slave I, Theisen BE, Rausch I, Weber M, Happak W, Aszmann O, Hojreh A, Peyrl A, Amann G, Benkoe TM, Wadsak W, Kasprian G, Staudenherz A, Hacker M and Traub-Weidinger T: Monitoring of plexiform neurofibroma in children and adolescents with neurofibromatosis type 1 by [(18) f]FDG-PET imaging. Is it of value in asymptomatic patients? Pediatr Blood Cancer 65(1), 2018. PMID: 28771999. DOI: 10.1002/pbc.26733

17 Berzaczy D, Mayerhoefer ME, Azizi AA, Haug AR, Senn D, Beitzke D, Weber $M$ and Traub-Weidinger T: Does elevated glucose metabolism correlate with higher cell density in neurofibromatosis type 1 associated peripheral nerve sheath tumors? PLoS One 12(12): e0189093, 2017. PMID: 29206885. DOI: 10.1371 journal.pone.0189093

18 Tovmassian D, Abdul Razak M and London K: The role of [(18)f]FDG-PET/CT in predicting malignant transformation of plexiform neurofibromas in neurofibromatosis-1. Int J Surg Oncol 2016: 6162182, 2016. PMID: 28058117. DOI: $10.1155 / 2016 / 6162182$

19 Ferner RE, Golding JF, Smith M, Calonje E, Jan W, Sanjayanathan V and O'Doherty M: [18f]2-fluoro-2-deoxy-dglucose positron emission tomography (FDG PET) as a diagnostic tool for neurofibromatosis 1 (NF1) associated malignant peripheral nerve sheath tumours (MPNSTs): A longterm clinical study. Ann Oncol 19(2): 390-394, 2008. PMID: 17932395. DOI: $10.1093 /$ annonc/mdm450

20 Broski SM, Johnson GB, Howe BM, Nathan MA, Wenger DE, Spinner RJ and Amrami KK: Evaluation of (18)f-FDG PET and MRI in differentiating benign and malignant peripheral nerve sheath tumors. Skeletal Radiol 45(8): 1097-1105, 2016. PMID: 27115884. DOI: 10.1007/s00256-016-2394-7

21 Raad RA, Lala S, Allen JC, Babb J, Mitchell CW, Franceschi AM, Yohay K and Friedman KP: Comparison of hybrid 18ffluorodeoxyglucose positron emission tomography/magnetic resonance imaging and positron emission tomography/computed tomography for evaluation of peripheral nerve sheath tumors in patients with neurofibromatosis type 1. World J Nucl Med 17(4): 241-248, 2018. PMID: 30505221. DOI: 10.4103/wjnm.WJNM -71_17

22 Blakeley JO and Plotkin SR: Therapeutic advances for the tumors associated with neurofibromatosis type 1, type 2, and schwannomatosis. Neuro Oncol 18(5): 624-638, 2016. PMID: 26851632. DOI: $10.1093 /$ neuonc/nov200

23 Upadhyaya M, Osborn MJ, Maynard J, Kim MR, Tamanoi F and Cooper DN: Mutational and functional analysis of the neurofibromatosis type 1 (NF1) gene. Hum Genet 99(1): 88-92, 1997. PMID: 9003501.

24 Tomlinson IP, Roylance R and Houlston RS: Two hits revisited again. J Med Genet 38(2): 81-85, 2001. PMID: 11158170. DOI: 10.1136/jmg.38.2.81

25 Riccardi VM: Neurofibromatosis type 1 is a disorder of dysplasia: The importance of distinguishing features, consequences, and complications. Birth Defects Res A Clin Mol Teratol 88(1): 9-14, 2010. PMID: 19691086. DOI: 10.1002/bdra.20616

26 Staser K, Yang FC and Clapp DW: Pathogenesis of plexiform neurofibroma: Tumor-stromal/hematopoietic interactions in tumor progression. Annu Rev Pathol 7: 469-495, 2012. PMID: 22077553. DOI: 10.1146/annurev-pathol-011811-132441

$27 \mathrm{Wu} \mathrm{LN}$ and $\mathrm{Lu} \mathrm{QR}$ : Therapeutic targets for malignant peripheral nerve sheath tumors. Future Neurol 14(1), 2019. DOI: 10.2217/fnl-2018-0026

28 Ferner RE, Huson SM, Thomas N, Moss C, Willshaw H, Evans DG, Upadhyaya M, Towers R, Gleeson M, Steiger C and Kirby A: Guidelines for the diagnosis and management of individuals with neurofibromatosis 1. J Med Genet 44(2): 81-88, 2007. PMID: 17105749. DOI: $10.1136 /$ jmg.2006.045906 
29 Wise JB, Cryer JE, Belasco JB, Jacobs I and Elden L: Management of head and neck plexiform neurofibromas in pediatric patients with neurofibromatosis type 1. Arch Otolaryngol Head Neck Surg 131(8): 712-718, 2005. PMID: 16103304. DOI: 10.1001/archotol.131.8.712

30 Avery RA, Katowitz JA, Fisher MJ, Heidary G, Dombi E, Packer RJ, Widemann BC and Group OW: Orbital/periorbital plexiform neurofibromas in children with neurofibromatosis type 1: Multidisciplinary recommendations for care. Ophthalmology 124(1): 123-132, 2017. PMID: 27817916. DOI: 10.1016/j.ophtha.2016.09.020

31 Goertz O, Langer S, Uthoff D, Ring A, Stricker I, Tannapfel A and Steinau HU: Diagnosis, treatment and survival of 65 patients with malignant peripheral nerve sheath tumors. Anticancer Res 34(2): 777-783, 2014. PMID: 24511012.

32 Friedrich RE and Diekmeier C: Peripheral nerve sheath tumors of the upper extremity and hand in patients with neurofibromatosis type 1: Topography of tumors and evaluation of surgical treatment in 62 patients. GMS Interdiscip Plast Reconstr Surg DGPW 6: Doc15, 2017. PMID: 29214122. DOI: 10.3205/iprs000117

33 Dombi E, Baldwin A, Marcus LJ, Fisher MJ, Weiss B, Kim A, Whitcomb P, Martin S, Aschbacher-Smith LE, Rizvi TA, Wu J, Ershler R, Wolters P, Therrien J, Glod J, Belasco JB, Schorry E, Brofferio A, Starosta AJ, Gillespie A, Doyle AL, Ratner N and Widemann BC: Activity of selumetinib in neurofibromatosis type 1-related plexiform neurofibromas. N Engl J Med 375(26): 25502560, 2016. PMID: 28029918. DOI: 10.1056/NEJMoa1605943

34 Guha D, Davidson B, Nadi M, Alotaibi NM, Fehlings MG, Gentili F, Valiante TA, Tator CH, Tymianski M, Guha A and Zadeh G: Management of peripheral nerve sheath tumors: 17 years of experience at toronto western hospital. J Neurosurg 128(4): 1226-1234, 2018. PMID: 28686119. DOI: 10.3171/2017.1.JNS162292

35 Chen L, Guo C, Song X, Yan C and Hu X: Long-term results for a one-stage surgery technique for patients with craniofacial plexiform neurofibroma. J Craniofac Surg 29(8): e746-e750, 2018. PMID: 29944556. DOI: 10.1097/SCS .0000000000004685

36 Nguyen R, Ibrahim C, Friedrich RE, Westphal M, Schuhmann $M$ and Mautner VF: Growth behavior of plexiform neurofibromas after surgery. Genet Med 15(9): 691-697, 2013 PMID: 23598713. DOI: 10.1038/gim.2013.30

37 Desai KI: The surgical management of symptomatic benign peripheral nerve sheath tumors of the neck and extremities: An experience of 442 cases. Neurosurgery 81(4): 568-580, 2017. PMID: 28475798. DOI: 10.1093/neuros/nyx076

38 Dozois EJ, Wall JC, Spinner RJ, Jacofsky DJ, Yaszemski MJ, Sim FH, Moran SL, Cima RR, Larson DR, Haddock MG, Okuno SH and Larson DW: Neurogenic tumors of the pelvis: Clinicopathologic features and surgical outcomes using a multidisciplinary team. Ann Surg Oncol 16(4): 1010-1016, 2009. PMID: 19194756. DOI: 10.1245/s10434-009-0344-5

39 Kim SM, Seo SW, Lee JY and Sung KS: Surgical outcome of schwannomas arising from major peripheral nerves in the lower limb. Int Orthop 36(8): 1721-1725, 2012. PMID: 22562391. DOI: $10.1007 / \mathrm{s} 00264-012-1560-3$

40 Mizushima H: Neurological deficits before and after surgical resection of schwannomas in the upper extremities. J Reconstr Microsurg 32(5): 371-377, 2016. PMID: 26872028. DOI: $10.1055 / \mathrm{s}-0036-1571798$
41 Caleffi E and Boschi E: Surgical excision of plexiform neurofibromas with compartmentalization's technique. 17th European NF Meeting 2016, Padova: 65, 2016 (abstract).

42 Mrowczynski O, Mau C, Nguyen DT, Sarwani N, Rizk E and Harbaugh K: Percutaneous radiofrequency ablation for the treatment of peripheral nerve sheath tumors: A case report and review of the literature. Cureus 10(4): e2534, 2018. PMID: 29946502. DOI: $10.7759 /$ cureus.2534

43 Zhao M, Li X, Wang J, Li W and Huang Z: Retroperitoneal schwannoma treated with percutaneous computed tomographyguided radiofrequency ablation. J Neurosurg Spine 17(2): 173176, 2012. PMID: 22657948. DOI: 10.3171/2012.4. SPINE111061

44 Sanchez Y, Shenoy-Bhangle A, Prabhakar AM, Gee MS, Fintelmann FJ and Uppot RN: Percutaneous image-guided cryotherapy for local control of recurrent plexiform schwannoma in a 3-year-old male. J Vasc Interv Radiol 28(5): 766-768, 2017. PMID: 28431654. DOI: 10.1016/j.jvir.2017.02.010

45 Mavrovi E, Vaz G, Thiesse P and Richioud B: Percutaneous cryoablation: A promising treatment for peripheral schwannoma. Diagn Interv Imaging 97(9): 923-925, 2016. PMID: 27316572. DOI: $10.1016 /$ j.diii.2016.05.005

46 Martell B, Jesse MK and Lowry P: CT-guided cryoablation of a peripheral nerve sheath tumor. J Vasc Interv Radiol 27(1): 148150, 2016. PMID: 26723927. DOI: 10.1016/j.jvir.2015.06.022

47 Yan B, Meng X, Shi B, Shi J, Qin Z and Wei P: A retroperitoneal NF1-independent malignant peripheral nerve sheath tumor with elevated serum CA125: Case report and discussion. J Neurooncol 109(1): 205-211, 2012. PMID: 22528792. DOI: 10.1007/s11060-012-0865-9

48 Burki TK: Selumetinib for children with plexiform neurofibromas. Lancet Oncol 18(2): e69, 2017. PMID: 28089105. DOI: 10.1016/S1470-2045(17)30009-8

49 Papalia H, Audic F, Riviere GR, Verschuur A and Andre N: Quick and sustained clinical response to mek inhibitor i in a NF1 patient with neurofibromas. Ecancermedicalscience 12: 862, 2018. PMID: 30174724. DOI: 10.3332/ecancer.2018.862

50 Vaassen P, Durr N, Rohrig A, Willing R and Rosenbaum T: Trametinib induces neurofibroma shrinkage and enables surgery. Neuropediatrics, 2019. PMID: 31141829. DOI: 10.1055/s-00391691830

51 https://clinicaltrials.gov/ [Last accessed on 26th January 2020]

52 Robertson KA, Nalepa G, Yang FC, Bowers DC, Ho CY, Hutchins GD, Croop JM, Vik TA, Denne SC, Parada LF, Hingtgen CM, Walsh LE, Yu M, Pradhan KR, Edwards-Brown MK, Cohen MD, Fletcher JW, Travers JB, Staser KW, Lee MW, Sherman MR, Davis CJ, Miller LC, Ingram DA and Clapp DW: Imatinib mesylate for plexiform neurofibromas in patients with neurofibromatosis type 1: A phase 2 trial. Lancet Oncol 13(12): 1218-1224, 2012. PMID: 23099009. DOI: 10.1016/S14702045(12)70414-X

53 Ardern-Holmes SL and North KN: Treatment for plexiform neurofibromas in patients with NF1. Lancet Oncol 13(12): 11751176, 2012. PMID: 23099008. DOI: 10.1016/S1470-2045(12) 70435-7

54 Wei J, Freytag M, Schober Y, Nockher WA, Mautner VF, Friedrich RE, Manley PW, Kluwe L and Kurtz A: Nilotinib is more potent than imatinib for treating plexiform neurofibroma in vitro and in vivo. PLoS One 9(10): e107760, 2014. PMID: 25340526. DOI: 10.1371/journal.pone. 0107760 
55 Ferguson MJ, Rhodes SD, Jiang L, Li X, Yuan J, Yang X, Zhang S, Vakili ST, Territo P, Hutchins G, Yang FC, Ingram DA, Clapp DW and Chen S: Preclinical evidence for the use of sunitinib malate in the treatment of plexiform neurofibromas. Pediatr Blood Cancer 63(2): 206-213, 2016. PMID: 26375012 DOI: $10.1002 / \mathrm{pbc} .25763$

56 Kim A, Dombi E, Tepas K, Fox E, Martin S, Wolters P, Balis FM, Jayaprakash N, Turkbey B, Muradyan N, Choyke PL, Reddy A, Korf B and Widemann BC: Phase I trial and pharmacokinetic study of sorafenib in children with neurofibromatosis type I and plexiform neurofibromas. Pediatr Blood Cancer 60(3): 396-401, 2013. PMID: 22961690. DOI: $10.1002 /$ pbc. 24281

57 Viskochil D and Combemale P: Nf105: A neurofibromatosis clinical trials consortium (NFCTC) phase ii study of cabozatinib (x1184) for neurofibromatosis type 1 associated plexiform neurofibromas. Joint Global Neurofibromatosis Conference, Paris 2018: 53, 2018 (abstract).

58 Jakacki RI, Dombi E, Steinberg SM, Goldman S, Kieran MW, Ullrich NJ, Pollack IF, Goodwin A, Manley PE, Fangusaro J, Allen R and Widemann BC: Phase II trial of pegylated interferon alfa- $2 \mathrm{~b}$ in young patients with neurofibromatosis type 1 and unresectable plexiform neurofibromas. Neuro Oncol 19(2): 289297, 2017. PMID: 27510726. DOI: 10.1093/neuonc/now 158

59 Jakacki RI, Dombi E, Potter DM, Goldman S, Allen JC, Pollack IF and Widemann BC: Phase I trial of pegylated interferonalpha-2b in young patients with plexiform neurofibromas. Neurology 76(3): 265-272, 2011. PMID: 21242495. DOI: 10.1212/WNL.0b013e318207b031

60 Kebudi R, Cakir FB and Gorgun O: Interferon-alpha for unresectable progressive and symptomatic plexiform neurofibromas. J Pediatr Hematol Oncol 35(3): e115-117, 2013. PMID: 23042022. DOI: 10.1097/MPH.0b013e318270cd24

61 Weiss B, Widemann BC, Wolters P, Dombi E, Vinks A, Cantor A, Perentesis J, Schorry E, Ullrich N, Gutmann DH, Tonsgard J, Viskochil D, Korf B, Packer RJ and Fisher MJ: Sirolimus for progressive neurofibromatosis type 1-associated plexiform neurofibromas: A neurofibromatosis clinical trials consortium phase II study. Neuro Oncol 17(4): 596-603, 2015. PMID: 25314964. DOI: 10.1093/neuonc/nou235

62 Zehou O, Ferkal S, Brugieres P, Barbarot S, Bastuji-Garin S, Combemale P, Valeyrie-Allanore L, Sbidian E and Wolkenstein P: Absence of efficacy of everolimus in neurofibromatosis 1related plexiform neurofibromas: Results from a phase 2a trial. J Invest Dermatol 139(3): 718-720, 2019. PMID: 30339775. DOI: $10.1016 /$ j.jid.2018.09.016

63 Hua C, Zehou O, Ducassou S, Minard-Colin V, Hamel-Teillac D, Wolkenstein P and Valeyrie-Allanore L: Sirolimus improves pain in NF1 patients with severe plexiform neurofibromas. Pediatrics 133(6): e1792-1797, 2014. PMID: 24864177. DOI: 10.1542/peds.2013-1224

64 Wang S, Liechty B, Patel S, Weber JS, Hollmann TJ, Snuderl M and Karajannis MA: Programmed death ligand 1 expression and tumor infiltrating lymphocytes in neurofibromatosis type 1 and 2 associated tumors. J Neurooncol 138(1): 183-190, 2018. PMID: 29427150. DOI: 10.1007/s11060-018-2788-6

65 Czarnecka AM, Sobczuk P, Zdzienicki M, Spalek M and Rutkowski P: Malignant peripheral nerve sheath tumor (MPNST). Oncol Clin Pract 14(6): 364-376, 2018. DOI: 10.5603/OCP.2018.0050
66 Higham CS, Steinberg SM, Dombi E, Perry A, Helman LJ, Schuetze SM, Ludwig JA, Staddon A, Milhem MM, Rushing D, Jones RL, Livingston M, Goldman S, Moertel C, Wagner L, Janhofer D, Annunziata CM, Reinke D, Long L, Viskochil D, Baker L and Widemann BC: Sarc006: Phase II trial of chemotherapy in sporadic and neurofibromatosis type 1 associated chemotherapy-naive malignant peripheral nerve sheath tumors. Sarcoma 2017: 8685638, 2017. PMID: 29138631. DOI: $10.1155 / 2017 / 8685638$

67 Gronchi A, Ferrari S, Quagliuolo V, Broto JM, Pousa AL, Grignani G, Basso U, Blay JY, Tendero O, Beveridge RD, Ferraresi V, Lugowska I, Merlo DF, Fontana V, Marchesi E, Donati DM, Palassini E, Palmerini E, De Sanctis R, Morosi C, Stacchiotti S, Bague S, Coindre JM, Dei Tos AP, Picci P, Bruzzi P and Casali PG: Histotype-tailored neoadjuvant chemotherapy versus standard chemotherapy in patients with high-risk soft-tissue sarcomas (ISGSTS 1001): An international, open-label, randomised, controlled, phase 3, multicentre trial. Lancet Oncol 18(6): 812-822, 2017. PMID: 28499583. DOI: 10.1016/S1470-2045(17)30334-0

68 Gronchi A, Stacchiotti S, Verderio P, Ferrari S, Martin Broto J, Lopez-Pousa A, Llombart-Bosch A, Dei Tos AP, Collini P, Jurado JC, De Paoli A, Donati DM, Poveda A, Quagliuolo V, Comandone A, Grignani G, Morosi C, Messina A, De Sanctis R, Bottelli S, Palassini E, Casali PG and Picci P: Short, full-dose adjuvant chemotherapy (CT) in high-risk adult soft tissue sarcomas (STS): Long-term follow-up of a randomized clinical trial from the italian sarcoma group and the spanish sarcoma group. Ann Oncol 27(12): 2283-2288, 2016. PMID: 27733375. DOI: 10.1093/annonc/mdw430

69 Kroep JR, Ouali M, Gelderblom H, Le Cesne A, Dekker TJ, Van Glabbeke M, Hogendoorn PC and Hohenberger P: First-line chemotherapy for malignant peripheral nerve sheath tumor (MPNST) versus other histological soft tissue sarcoma subtypes and as a prognostic factor for MPNST: An EORTC soft tissue and bone sarcoma group study. Ann Oncol 22(1): 207-214, 2011. PMID: 20656792. DOI: 10.1093/annonc/mdq338

70 Pervaiz N, Colterjohn N, Farrokhyar F, Tozer R, Figueredo A and Ghert $\mathrm{M}$ : A systematic meta-analysis of randomized controlled trials of adjuvant chemotherapy for localized resectable soft-tissue sarcoma. Cancer 113(3): 573-581, 2008. PMID: 18521899. DOI: 10.1002/cncr.23592

71 Hirbe AC, Cosper PF, Dahiya S and Van Tine BA: Neoadjuvant ifosfamide and epirubicin in the treatment of malignant peripheral nerve sheath tumors. Sarcoma 2017: 3761292, 2017. PMID: 28546782. DOI: $10.1155 / 2017 / 3761292$

72 Madhankumar AB, Mrowczynski OD, Slagle-Webb B, Ravi V, Bourcier AJ, Payne R, Harbaugh KS, Rizk E and Connor JR: Tumor targeted delivery of doxorubicin in malignant peripheral nerve sheath tumors. PLoS One 13(1): e0181529, 2018. PMID: 29304038. DOI: 10.1371/journal.pone.0181529

73 Akhavan A, Binesh F, Ghannadi F and Navabii H: Excellent response of malignant peripheral nerve sheath tumour of retroperitoneum to radiation therapy. BMJ Case Rep 2012: 2012. PMID: 23257269. DOI: 10.1136/bcr-2012-007266

74 Vitolo V, Fiore MR, Barcellini A, Vischioni B, Iannalfi A, Facoetti A, Fossati P, Bonora M, Ronchi S, D'Ippolito E, Petrucci R, Viselner G, Ciocca M, Preda L, Valvo F and Orecchia R: Carbon ion radiotherapy in the management of the tumors of the peripheral nervous system. Anticancer Res 39(2): 909-913, 2019. PMID: 30711975. DOI: 10.21873/anticanres.13193 
75 Bishop AJ, Zagars GK, Torres KE, Bird JE, Feig BW and Guadagnolo BA: Malignant peripheral nerve sheath tumors: A single institution's experience using combined surgery and radiation therapy. Am J Clin Oncol 41(5): 465-470, 2018. PMID: 27281262. DOI: $10.1097 / C O C .0000000000000303$

76 DeLaney TF, Liebsch NJ, Pedlow FX, Adams J, Weyman EA, Yeap BY, Depauw N, Nielsen GP, Harmon DC, Yoon SS, Chen YL, Schwab JH and Hornicek FJ: Long-term results of phase II study of high dose photon/proton radiotherapy in the management of spine chordomas, chondrosarcomas, and other sarcomas. J Surg Oncol 110(2): 115-122, 2014. PMID: 24752878. DOI: $10.1002 /$ jso.23617

77 Jensen AD, Uhl M, Chaudhri N, Herfarth KK, Debus J and Roeder F: Carbon ion irradiation in the treatment of grossly incomplete or unresectable malignant peripheral nerve sheaths tumors: Acute toxicity and preliminary outcome. Radiat Oncol 10: 109, 2015. PMID: 25943106. DOI: 10.1186/s13014-0150414-8

78 Kahn J, Gillespie A, Tsokos M, Ondos J, Dombi E, Camphausen $\mathrm{K}$, Widemann BC and Kaushal A: Radiation therapy in management of sporadic and neurofibromatosis type 1-associated malignant peripheral nerve sheath tumors. Front Oncol 4: 324, 2014. PMID: 25452937. DOI: 10.3389/fonc.2014.00324

79 Sloan L: Long-term outcomes of radiation therpy (RT) in the management of malignant peripheral nerve sheath tumors (MPNST) in patients with neurofibromatosis type 1. Joint Global Neurofibromatosis Conference, Paris 2018: 53, 2018 (abstract).

80 Widemann BC, Dombi E, Gillespie A, Wolters PL, Belasco J, Goldman S, Korf BR, Solomon J, Martin S, Salzer W, Fox E, Patronas N, Kieran MW, Perentesis JP, Reddy A, Wright JJ, Kim A, Steinberg SM and Balis FM: Phase 2 randomized, flexible crossover, double-blinded, placebo-controlled trial of the farnesyltransferase inhibitor tipifarnib in children and young adults with neurofibromatosis type 1 and progressive plexiform neurofibromas. Neuro Oncol 16(5): 707-718, 2014. PMID: 24500418. DOI: 10.1093/neuonc/nou004

81 Widemann BC, Babovic-Vuksanovic D, Dombi E, Wolters PL, Goldman S, Martin S, Goodwin A, Goodspeed W, Kieran MW, Cohen B, Blaney SM, King A, Solomon J, Patronas N, Balis FM, Fox E, Steinberg SM and Packer RJ: Phase II trial of pirfenidone in children and young adults with neurofibromatosis type 1 and progressive plexiform neurofibromas. Pediatr Blood Cancer 61(9): 1598-1602, 2014. PMID: 24753394. DOI: $10.1002 /$ pbc. 25041

82 Babovic-Vuksanovic D, Ballman K, Michels V, McGrann P, Lindor N, King B, Camp J, Micic V, Babovic N, Carrero X, Spinner R and O'Neill B: Phase II trial of pirfenidone in adults with neurofibromatosis type 1. Neurology 67(10): 1860-1862, 2006. PMID: 17035676. DOI: 10.1212/01.wnl.0000243231.12248.67

83 Peacock JD, Pridgeon MG, Tovar EA, Essenburg CJ, Bowman M, Madaj Z, Koeman J, Boguslawski EA, Grit J, Dodd RD, Khachaturov V, Cardona DM, Chen M, Kirsch DG, Maina F, Dono R, Winn ME, Graveel CR and Steensma MR: Genomic status of MET potentiates sensitivity to MET and MEK inhibition in NF1-related malignant peripheral nerve sheath tumors. Cancer Res 78(13): 3672-3687, 2018. PMID: 29720369. DOI: $10.1158 / 0008-5472 . C A N-17-3167$

84 Kivlin CM, Watson KL, Al Sannaa GA, Belousov R, Ingram DR, Huang KL, May CD, Bolshakov S, Landers SM, Kalam AA, Slopis JM, McCutcheon IE, Pollock RE, Lev D, Lazar AJ and Torres KE: Poly (ADP) ribose polymerase inhibition: A potential treatment of malignant peripheral nerve sheath tumor. Cancer Biol Ther 17(2): 129-138, 2016. PMID: 26650448. DOI: 10.1080/15384047.2015.1108486

85 Bryant JK: Targeting the hyaluronan-rich peripheral nerve sheath tumor microenvironment to improve drug efficacy and delivery. Joint Global Neurofibromatosis Conference, Paris 2018: 43, 2018 (abstract).

86 Esposito T, Schettino C, Polverino P, Allocca S, Adelfi L, D'Amico A, Capaldo G, Varriale B, Di Salle A, Peluso G, Sorrentino G, Lus G, Sampaolo S, Di Iorio G and Melone MAB: Synergistic interplay between curcumin and polyphenol-rich foods in the mediterranean diet: Therapeutic prospects for neurofibromatosis 1 patients. Nutrients 9(7), 2017. PMID: 28754004. DOI: $10.3390 /$ nu 9070783

87 Ling BC, Wu J, Miller SJ, Monk KR, Shamekh R, Rizvi TA, Decourten-Myers G, Vogel KS, DeClue JE and Ratner N: Role for the epidermal growth factor receptor in neurofibromatosisrelated peripheral nerve tumorigenesis. Cancer Cell 7(1): 65-75, 2005. PMID: 15652750. DOI: 10.1016/j.ccr.2004.10.016

88 Reuss DE, Mucha J, Hagenlocher C, Ehemann V, Kluwe L, Mautner V and von Deimling A: Sensitivity of malignant peripheral nerve sheath tumor cells to TRAIL is augmented by loss of NF1 through modulation of MYC/MAD and is potentiated by curcumin through induction of ROS. PLoS One $8(2)$ : e57152, 2013. PMID: 23437333. DOI: 10.1371/journal.pone.0057152

89 Fischer-Huchzermeyer S, Dombrowski A, Wilke G, Stahn V, Streubel A, Mautner VF and Harder A: MEK inhibitors enhance therapeutic response towards ATRA in NF1 associated malignant peripheral nerve sheath tumors (MPNST) in vitro. PLoS One 12(11): e0187700, 2017. PMID: 29131833. DOI: 10.1371/journal.pone. 0187700

90 Staedtke VS: Feasibility of gene replacement therapy in nf1related mpnst. Joint Global Neurofibromatosis Conference, Paris 2018: 53, 2018 (abstract).

91 Deyle DR, Escobar DZ, Peng KW and Babovic-Vuksanovic D: Oncolytic measles virus as a novel therapy for malignant peripheral nerve sheath tumors. Gene 565(1): 140-145, 2015. PMID: 25843626. DOI: 10.1016/j.gene.2015.04.001

92 Sehgal VN, Srivastava G, Aggarwal AK and Oberai R: Plexiform neurofibromas in neurofibromatosis type 1 . Int $\mathbf{J}$ Dermatol 48(9): 971-974, 2009. PMID: 19702982. DOI: 10.1111/j.1365-4632.2008.04041.x

93 Kamran SC, Shinagare AB, Howard SA, Hornick JL and Ramaiya NH: A-Z of malignant peripheral nerve sheath tumors. Cancer Imaging 12: 475-483, 2012. PMID: 23108260. DOI: 10.1102/1470-7330.2012.0043

94 Kolberg M, Bruun J, Murumagi A, Mpindi JP, Bergsland CH, Holand M, Eilertsen IA, Danielsen SA, Kallioniemi O and Lothe RA: Drug sensitivity and resistance testing identifies PLK1 inhibitors and gemcitabine as potent drugs for malignant peripheral nerve sheath tumors. Mol Oncol 11(9): 1156-1171, 2017. PMID: 28556483. DOI: 10.1002/1878-0261.12086

Received February 25, 2020

Revised March 6, 2020

Accepted March 10, 2020 